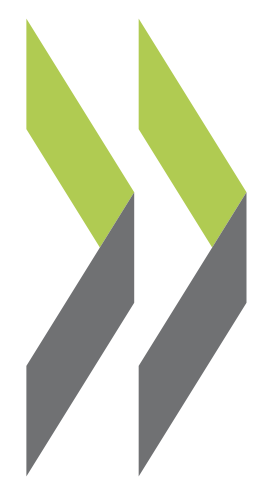

OECD Economics Department Working Papers No. 660

Can the Financial Sector continue to be the Main Growth Engine in Luxembourg?

\author{
Arnaud Bourgain, \\ Patrice Pieretti, \\ Jens Høj
}


Organisation de Coopération et de Développement Économiques

Organisation for Economic Co-operation and Development

15-Jan-2009

ECONOMICS DEPARTMENT

English - Or. English

CAN THE FINANCIAL SECTOR CONTINUE TO BE THE MAIN GROWTH ENGINE IN

LUXEMBOURG?

ECONOMICS DEPARTMENT WORKING PAPER No. 660

By

Arnaud Bourgain, Patrice Pieretti and Jens Høj

All Economics Department Working Papers are available through OECD's internet web site at www.oecd.org/eco/Working_Papers

JT03258258

Document complet disponible sur OLIS dans son format d'origine

Complete document available on OLIS in its original format 


\section{ABSTRACT/ RÉSUMÉ \\ Can the financial sector continue to be the main growth engine in Luxembourg?}

The financial sector has emerged as the main economic engine over the past two decades. The comparative advantages of placing financial activities in Luxembourg have mostly been in terms of an adaptive legislative and regulatory framework and low taxation. As a result, Luxembourg is today one of the main international centres for investment funds. Besides the sector's direct and indirect employment effects, the most important effect is the large tax revenue generating capacity of the sector, accounting directly for over $20 \%$ of aggregate tax revenues. On the other hand, these tax revenues are volatile as the sector is highly sensitive to developments in international financial markets. Indeed, past downturns in international financial markets have tended to lead to a sharp slowdown of growth in the economy as well as in revenues, pointing to potential large risks associated with the current turmoil in international financial markets. Besides these short-term considerations, a lower trend growth rate of the sector is likely over the medium term. The main activities of the sector are in middle and back offices dealing with financial administration which, with new IT technologies, will tend to be increasingly outsourced. At the same time, the sector is having problems in attracting highly specialised talent to enter higher value front office activities. Over the longer term, international competition will continue to exert pressures that may eventually erode Luxembourg's position. The extent of the decline in the sector's trend growth depends on the ability to maintain and expand the attractiveness of investing and working in Luxembourg. Achieving this will depend on being able to adjust tax, infrastructure, and housing policies to attract foreign talent while updating and increasing the transparency of financial sector regulation.

This Working Paper relates to the 2008 OECD Economic Survey of Luxembourg (www.oecd.org/eco/surveys/luxembourg).

JEL classification: G15; G18; G21; G24.

Keywords: Financial sector; Luxembourg; comparative advantages; public finances; economic growth.

$$
* * * * * * *
$$

\section{Le secteur financier peut-il rester le principal moteur de la croissance au Luxembourg ?}

Le secteur financier a été le principal moteur de l'économie au cours des deux dernières décennies. Les avantages comparatifs du Luxembourg en matière d'activités financières résident essentiellement dans le caractère évolutif de son cadre législatif et réglementaire ainsi que dans le faible niveau de sa fiscalité. En conséquence, le Luxembourg est aujourd'hui un des principaux centres internationaux pour les fonds d'investissement. Au-delà des effets directs et indirects de ce secteur d'activité sur l'emploi, sa retombée la plus importante est l'ampleur des recettes fiscales qu'il permet aux pouvoirs publics d'engranger, puisqu'il représente directement plus de $20 \%$ de l'ensemble des rentrées d'impôts. Cela dit, ces recettes fiscales sont très fluctuantes, dans la mesure où ce secteur est extrêmement sensible à l'évolution des marchés de capitaux internationaux. De fait, les contractions intervenues par le passé sur ces marchés ont eu tendance à entrâ̂ner un net ralentissement de la croissance de l'économie luxembourgeoise ainsi que des revenus du secteur financier, ce qui laisse à penser que les risques associés aux turbulences financières internationales actuelles sont très substantiels. Au-delà de ces considérations à court terme, le taux de croissance tendanciel du secteur va probablement diminuer à moyen terme. Les principales activités du secteur sont les prestations d'administration financière correspondant aux services de suivi de marché et de postmarché, que les nouvelles technologies de l'information permettront de délocaliser de plus en plus. Par ailleurs, le secteur a des difficultés à attirer des spécialistes hautement qualifiés pour prendre pied dans le domaine plus rémunérateur des activités de service de clientèle. À plus long terme, la concurrence internationale continuera à exercer des pressions qui pourraient finir par remettre en cause la position du Luxembourg. L'ampleur du déclin de la croissance tendancielle du secteur financier dépendra de la capacité du Luxembourg à préserver et renforcer l'attrait qu'il exerce sur les investisseurs et les travailleurs. Pour ce faire, les autorités devront parvenir à adapter leurs politiques dans les domaines de la fiscalité, des infrastructures et du logement pour attirer des étrangers très compétents, tout en révisant la réglementation du secteur financier et en renforçant sa transparence.

Ce Document de travail se rapporte à l'Étude économique de l'OCDE du Luxembourg, 2008 (www.oecd.org/eco/etudes/luxembourg).

Classification JEL : G15 ; G18 ; G21 ; G24.

Mots clés: secteur financier ; Luxembourg ; avantages comparatifs ; finances publiques ; croissance économique.

Copyright OECD 2008

Application for permission to reproduce or translate all, or part of, this material should be made to:

Head of Publications Service, OECD, 2 rue André-Pascal, 75775 Paris Cedex 16, France. 


\section{TABLE OF CONTENTS}

\section{CAN THE FINANCIAL SECTOR CONTINUE TO BE THE MAIN GROWTH ENGINE IN} LUXEMBOURG? 5

The financial sector in Luxembourg - dependence and challenges ......................................................... 5

The Luxembourg economy is highly dependent on the financial sector .......................................... 7

The financial-sector's revenues are very sensitive to the international financial cycle ......................... 11

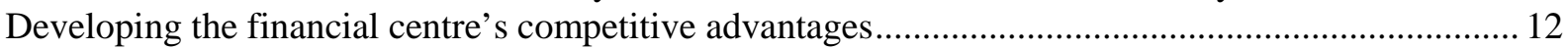

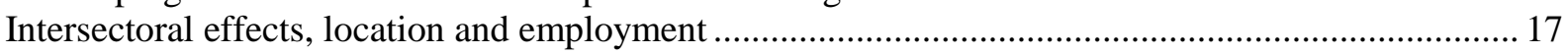

Development of the financial centre: challenges and strategies ..................................................... 19

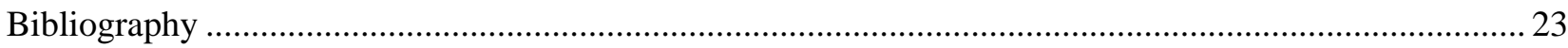

Annex A. Nonlinear model of the relationship between European stock index/bank income and

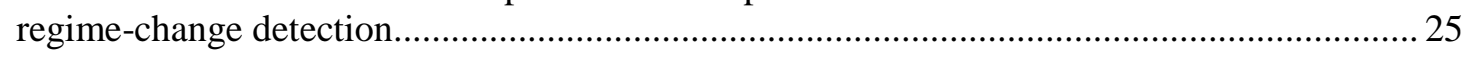

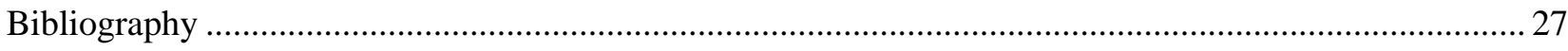

Annex B. Main recommendations in the OECD territorial review of Luxembourg ................................... 28

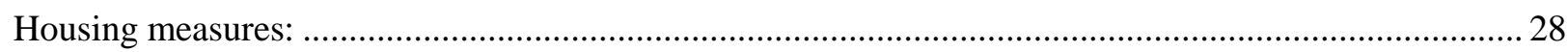

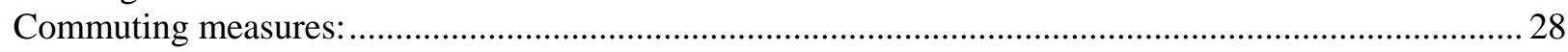

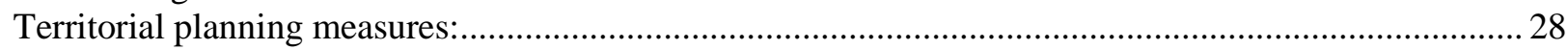

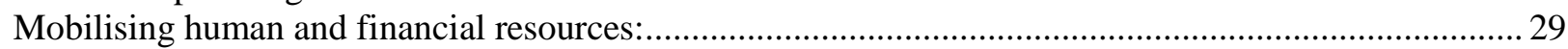

\section{Boxes}

1. The Luxembourg banking and finance centre: selected international comparisons..........................5

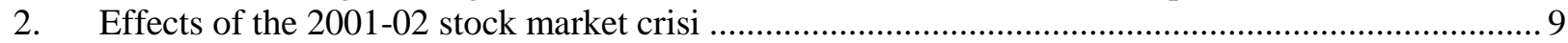

3. A brief account of Luxembourg's ascent as a financial centre ................................................. 12

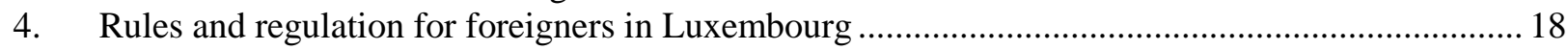

5. Summary of policy recommendations for the financial sector ................................................. 22

\section{Figures}

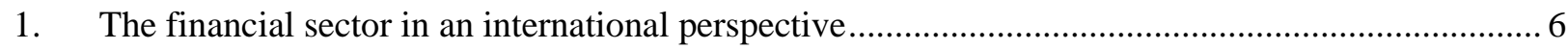

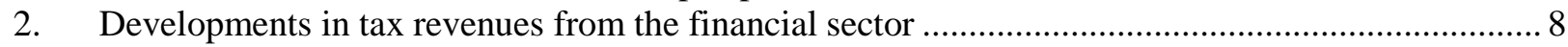

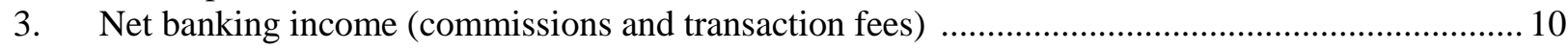

4. Developments in banking net income and European stock markets ............................................ 11 
ECO/WKP(2009)1 
ECO/WKP(2009)1

\title{
CAN THE FINANCIAL SECTOR CONTINUE TO BE THE MAIN GROWTH ENGINE IN LUXEMBOURG?
}

\author{
by \\ Arnaud Bourgain, Patrice Pieretti and Jens Høj ${ }^{1}$
}

\section{The financial sector in Luxembourg - dependence and challenges}

1. Few if any other OECD countries are as dependent on a single sector as Luxembourg is on the financial sector. The sector has emerged as the main economic engine, pulling not only employment in the sector itself, but also in supporting business services. Over the past decade, the dynamic tax revenues originating in the sector have contributed to finance the expansion of the public sector. This paper addresses the question of whether the economy can continue to rely on the financial sector as its main driver. The paper commences with assessing the scope and scale of this dependence. Then, the sensitivity of the sector to developments in international financial markets is evaluated. Thereafter, the development of the sector and its activities are treated in some details to allow for the subsequent assessment of the emerging challenges to the sector. Subsequently, various strategies for the sector to maintain its dynamism are discussed, before concluding with a set of policy recommendations.

2. Luxembourg began in earnest to develop as a banking and financial centre in the early $1980 \mathrm{~s}-\mathrm{a}$ time of financial-market liberalisation and integration - culminating in its current top-ranking position, primarily in the realm of asset management (Box 1). As a result, in the investment-fund sector, Luxembourg is the world's number-two financial centre, second only to New York, for assets under management by investment funds. The specialisation of the sector is in private banking, but financialengineering activities (holding companies, domiciliation, reinsurance, securitisation, etc.) are becoming important. In addition to 157 banks, there are some 30000 companies known as "special purpose entities" registered in Luxembourg (Schuller, 2005).

\section{Box 1. The Luxembourg banking and finance centre: selected international comparisons}

For lack of a composite indicator, comparisons between international financial centres are generally based on their respective market capitalisations. Using this criterion, Luxembourg does not emerge as a major centre. The capitalisation of the Luxembourg stock market is only $2 \%$ as great as that of Euronext or London. On the other hand, Luxembourg is a major centre in its main activity: administration and management of savings from the international market.

- $\quad$ Luxembourg is, together with the United Kingdom and Switzerland, a major net exporter of financial services (banking and insurance) (Figure 1, Panel A).

- Luxembourg ranks ninth in terms of external deposits from the non-bank sector. (Figure 1, Panel B)

1. Arnaud Bourgain and Patrice Pieretti are assistant professor and professor respectively, at the Institute of Economics, University at Luxembourg. Jens Høj is the head of the Benelux desk in the OECD. The paper first appeared as a chapter for the OECD Economics Survey of Luxembourg, published in July 2008 under the responsibility of the Economics and Development Review Committee. The authors are grateful to Patrick Lenain for his support and guidance for this work. They would also like to thank OECD colleagues Val Koromzay, Andrew Dean, Jean-Luc Schneider, Ekkehard Ernst and Cindy Veiga Nunes among others for useful comments, as well as Laure Meuro for statistical assistance and Heloise Wickramanayake for secretarial assistance. 
- Luxembourg is Europe's leading financial centre in terms of assets under management by investment funds ( $25 \%$ of the European market and $29 \%$ of the market for UCITS - Undertakings for Collective Investments in Transferable Securities) and number two in the world. (Figure 1, Panel C).

- Leading consultancies put Luxembourg third in terms of market share of international private-banking business (Figure 1, Panel D).

Figure 1. The financial sector in an international perspective
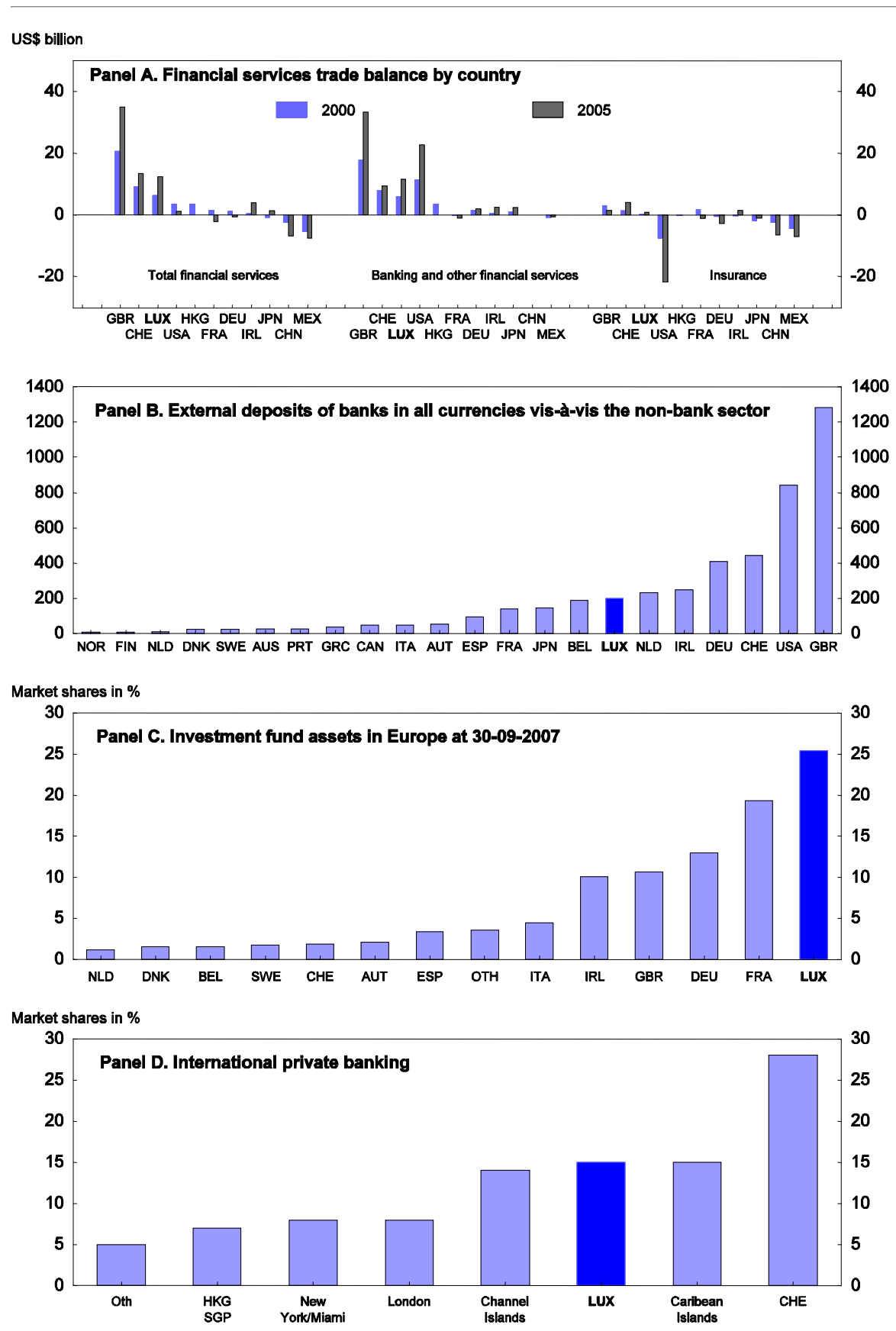

Source: International Financial Services London (IFSL), from IMF data; BRI; European Fund and Asset Management association (EFAMA); Boston Consulting Group. 


\section{The Luxembourg economy is highly dependent on the financial sector}

3. Delineating the boundaries of the financial sector is not a simple matter. In addition to banks and insurance companies, there are undertakings for collective investment (UCI) and "professionals of the financial sector" (PFS) - a high-growth category made up of investment companies (wealth managers, dealers, custodians, distributors of shares in UCI, etc.) and other businesses that are related or complementary to the financial sector (brokers, financial advisers, company domiciliation agents, etc.). In addition, a financial cluster is surrounded by a multitude of suppliers of highly diverse services, some of which are directly related to financial services (suppliers of computer services, auditing and consulting firms, investment-fund management companies, compensation and settlement bodies, fiduciaries, corporate lawyers and notaries).

4. Econometric estimates of the impact of the financial sector on the economy suggest that a $1 \%$ drop in financial-sector real value added would have a negative impact on the Luxembourg economy as a whole, with a first-year effect of a decline by $0.6 \%$ and in each of the following two years a decline of $0.3 \%$ (STATEC, 2008). ${ }^{2}$ In addition, the financial sector has a large impact on tax revenues. There are four main tax contributions from financial activities. The profit taxes paid by banks, insurance undertakings and other financial institutions are supplemented by revenue from the "subscription tax" on corporate securities. The subscription tax is an annual levy, essentially on mutual funds. Its standard rate is $0.05 \%$ of net assets, while some types of funds are eligible for a reduced rate of $0.01 \%$ of net assets or may even be tax-exempt. For 2006, the financial sector's "direct" contribution to aggregate tax revenue (including local taxes) was $22.5 \%$ (Table 1 ).

Table 1. Tax revenues from the financial sector (2006)

\begin{tabular}{lcc}
\hline & Amount (EUR million) & $\begin{array}{c}\text { As a \% of aggregate general } \\
\text { government tax revenue (\%) }\end{array}$ \\
\cline { 2 - 3 } Profit tax and miscellaneous taxes paid by banks & 904 & 10.4 \\
Profit tax paid by insurance and reinsurance & 115.2 & 1.3 \\
undertakings & & 4.4 \\
Profit tax paid by PFS and management companies & 288 & 7.5 \\
Subscription tax on corporate securities & 651.1 & 22.5 \\
Total & & \\
\hline
\end{tabular}

Sources: CSSF, CAA and STATEC.

5. The two main tax revenues (taxes paid by banks and subscription taxes) have grown strongly (especially in the 1990s) and have been relatively volatile (Figure 2, Panel A). With respect to the latter, three cyclical economic shocks stand out rather clearly, reflecting vulnerability to turbulence in international financial markets. In 1989-90 and in 1998, banks boosted their provisions sharply in the light of mounting risks in securities markets (developments in the Soviet Union in 1990; the Asian and Latin American crises in 1998). ${ }^{3}$ Together with other factors, such as a nearly 2 percentage point reduction in the corporate income tax rate, the taxes paid by banks declined by $19 \%$ in 1998. The stock market crash of 2001-02 (Box 2) affected tax revenue from both bank profits and subscription tax. Bank profits before provisions held up well to the international stock market downturn in 2001-02, but the sharp (82\%) rise in provisions fed through to a $22.6 \%$ drop in tax payments. At the time of the crash, the subscription tax proved highly vulnerable, with inflows falling by $25 \%$ between 2000 and 2002, and subsequently rebounding by $79 \%$ between 2003 and 2006 . As a consequence, the share of taxes paid by the financial

2. In addition, there are intersectoral effects leading to important growth dynamics, such as knowledge spillovers, labour-market pooling, and supply of intermediate goods.

3. Net bank provisions increased by 308\% in 1997 and by $71 \%$ in 1998 (see annual reports of the Banque centrale du Luxembourg). 
sector has been very volatile (Figure 2, Panel B). Tax revenues from PFS and insurers have been added to the figures for very recent years so as to observe the growth of these related activities, which is partly related to the fact that more financial intermediation is subcontracted to PFS - a trend that may partially explain the banks' declining relative share of aggregate tax revenue. ${ }^{4}$ This translates into a higher volatility of tax revenues than in other countries. For example, over the period 1991-2006, the standard deviation of the general government balance amounted to $2.2 \%$ of GDP in Luxembourg as compared with $1.3 \%$ in Germany and $1.4 \%$ in France (BCL, 2007).

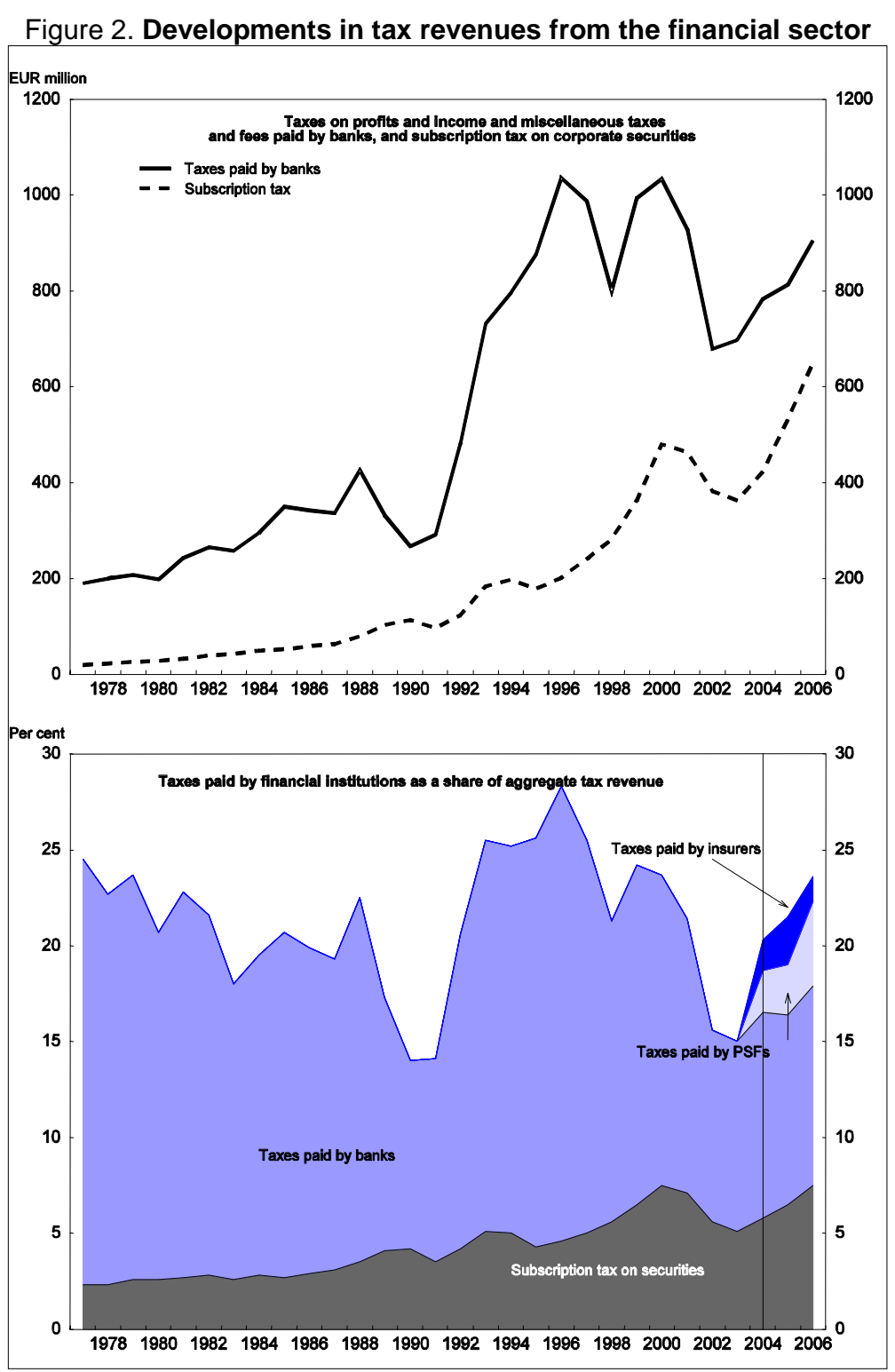

Source: STATEC, BCL, and CSSF.

4. The Act of 2 August 2003 reorganised the PFS sector, which is why uniform data for it are available only from 2004. 


\section{Box 2. Effects of the 2001-02 stock market crisis}

The sharp drop in stock market indices attributable to the "bursting of the Internet bubble", as well as to a number of financial scandals (Enron, Tyco, Arthur Andersen, etc.), stretched from late 2000 until early 2003 (primarily in 2001 and 2002). Between end third-quarter 2000 and end first-quarter 2003, the declines were: DJ EURO STOXX 50: -57\%; DAX: -62\%; CAC40: -56\%; Swiss Market Index: $-46 \%$.

Among the components of bank revenue, net non-interest income, comprised essentially of commissions and transaction fees, is inherently more dependent on variations caused by turbulence in international stock markets. Following the share price declines in 2001-02, the following decreases in net banking income were observed between end-2001 and end-2003: Germany: -30\%; Belgium: -19\%; France: -9\%; Luxembourg: $-4 \%$; Switzerland: $-20 \%$. The Figure 3 below illustrates the trends in these countries' net banking income and in the DJ EURO STOXX 50 index. The data must be interpreted with caution insofar as the share of aggregate bank revenue derived from commissions and transaction fees varies significantly from one country to another (e.g. $61 \%$ in Switzerland and 34\% in Germany in 2005).

The net banking income of Luxembourg banks was affected by the plunge in stock prices in 2001 and 2002, but its sensitivity to the decline was no greater than was the case in neighbouring European countries. Between 31 December 2001 and 31 December 2003, the aggregate balance-sheet assets of credit institutions, declined by $9 \%$. As noted previously, 2002 saw a sharp drop in Luxembourg tax revenue.

With regard to employment in the banking and PFS sector, the decline between end-2001 and end-2003 was $4 \%$, attributable essentially to the banking sector. In contrast, for 2002 the stock market turbulence alone does not fully explain the drop in banking-sector employment. According to the Luxembourg central bank, the wave of bank mergers, which was especially active at that time, was responsible for roughly $50 \%$ of the banks' job losses. Moreover, the outsourcing of certain functions had an impact on the number of purely banking jobs (BCL, 2003).

The repercussions of the crisis on the Luxembourg economy as a whole took the form of a significant cyclical slowdown. The fundamental indicators below show growth rates that remained clearly in the black between end-2001 and end-2003, albeit lower than the respective annual growth rates between 1995 and 2006 :

\begin{tabular}{lcc} 
& $\begin{array}{c}\text { Average annual growth } \\
\text { rates between end- } \\
2001 \text { and end-2003 } \\
(\%)\end{array}$ & $\begin{array}{c}\text { Average annual growth } \\
\text { rates between end-1995 } \\
\text { and end-2006 (\%) }\end{array}$ \\
\cline { 2 - 3 } GDP (at current prices) & +6.8 & +7.6 \\
GDP (at constant prices) & +3 & +5 \\
Tax revenue & +4.3 & +7 \\
Total employment & +2.5 & +3.6 \\
\hline
\end{tabular}

Source: STATEC.

The upswing in Luxembourg financial activity that followed the slowdown (with the financial sector's value added in current prices rising by $4 \%$ in $2004,22 \%$ in 2005 and $31 \%$ in 2006) is explained in part by the rebound in stock prices (Figure 4). However, it was also beginning in this period (2004) that special adjustment measures were taken, such as:

- A search for new private-banking clients in the wake of the savings tax directive (see below).

- Regulatory and financial innovation in the realm of securitisation and risk capital.

- Sharp expansion of the management of investment funds and products such as life insurance, etc.

It is difficult, however, to ascertain whether this movement was stimulated by the sensitivity of Luxembourg's financial activity to international financial turbulence. Moreover, it would be wrong simply to juxtapose the effects of the 2001-02 crisis and the current turbulence in international finance, as the two events may have distinct characteristics in terms of propagation and transmission mechanisms. 
Figure 3. Net banking income (commissions and transaction fees)
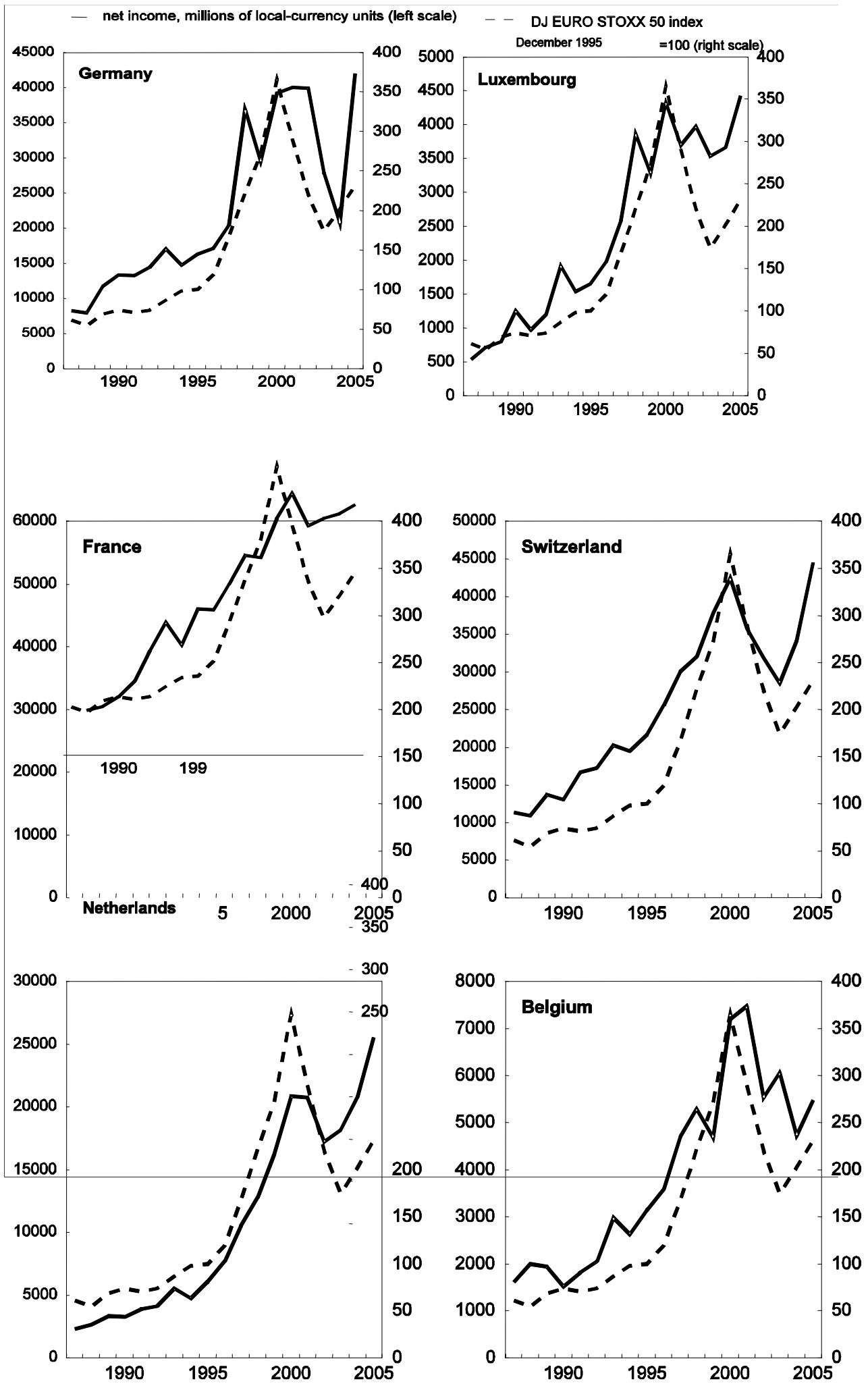

Source: OECD, Bank profitability-Financial Statements of Banks and Eurostat. 
Figure 4. Developments in banking net income and European stock markets

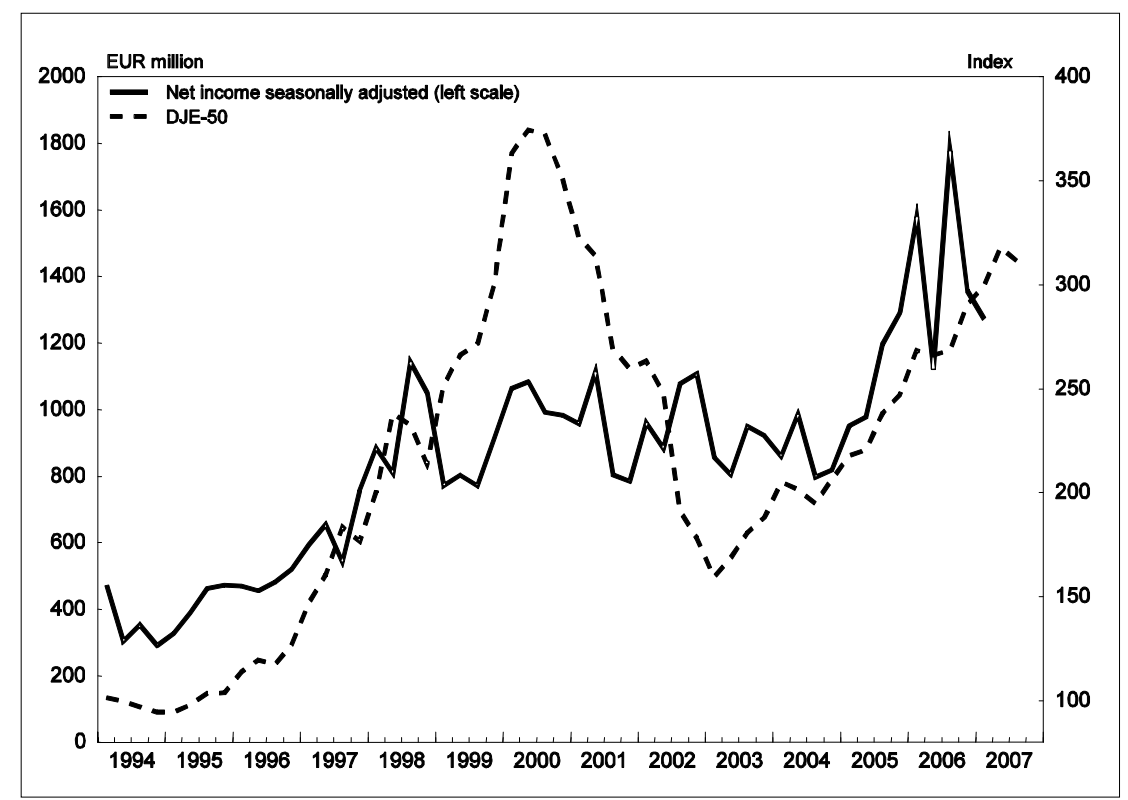

Source: BCL and Eurostat.

\section{The financial-sector's revenues are very sensitive to the international financial cycle}

6. The income structure of the Luxembourg financial sector, and especially its banks, has shifted considerably in recent decades. Income from conventional intermediation (interest income) has been declining steadily in relation to net income from commissions and transaction fees. Whereas such net income accounted for $15 \%$ of bank revenues in the early 1980 s, the proportion had risen to $55 \%$ by 2006 , with commissions accounting for two-thirds of this income. Since bank commissions are closely tied to the value of assets traded and managed, the matter of sensitivity to cyclical variations and turbulence on international securities markets becomes increasingly important, especially insofar as the growth of other, non-bank financial activities is based largely on securities transactions.

7. According to econometric studies on the sensitivity of banking income to international macroeconomic and stock market shocks, the constitution of provisions is negatively correlated with the European macroeconomic cycle, i.e. provisions for bad debts are higher in periods of slowdown (Rouabah, 2006; Lehmann and Manz, 2006). ${ }^{5}$ To a lesser extent, a rise in interest rates also heightens the constitution of provisions. ${ }^{6}$ As would be expected, the findings show that net income from commissions and transaction fees is significantly tied to the performance of financial markets (Figure 4). A $10 \%$ decline in the European stock market index feeds through to a nearly $10 \%$ average decrease in net income from commissions and transaction fees and with large banks seemingly more sensitive than small ones. Although, there is

5. A $10 \%$ drop in the quarterly growth rate of euro zone GDP for the previous quarter is estimated to trigger a $4.33 \%$ increase in provisions.

6. Net-interest income can be procyclical in relation to rising interest rates if rates are more rigid on bank liabilities than on bank assets. In such cases, rising interest rates increase the spread on bank intermediation. In Rouabah's study (2006), parameters concerning variations in interest rates are not significant in all of the estimations, whether static or dynamic, probably reflecting a tendency to act quickly to adjust rates on commitments in response to changing returns on assets. 
empirical evidence that the link has weakened over time (Annex A). Assuming that at least $50 \%^{7}$, a fall in net income from commissions and fees is passed on to real value added in the financial sector and given the calculated sensitivity of the economy as a whole to the financial sector (STATEC, 2008; Rouabah, 2006), then there are indications that a permanent $1 \%$ decline in the European stock index would have as much as a $-0.15 \%$ impact on the Luxembourg economy in the long term. ${ }^{8}$

8. With regard to the current US "subprime" financial crisis, the impact on Luxembourg's financial sector appears to be more indirect, involving contagion effects, rather than direct effects as noted above. The "indirect" effects of the subprime financial crisis, on the other hand, are still difficult to ascertain. A fall in confidence with regard to securitisation as a form of financial intermediation could be a bad sign for the "young" Luxembourg securitisation market. Judging from bank earnings reports for the third and fourth quarters of 2007, the income derived from the investment-fund and private-banking businesses does not really appear to have been affected by the financial crisis. Indeed for 2007 as a whole commission income was up by $8.8 \% .^{9}$ Nevertheless, turbulence in international financial markets has detrimental contagion effects in all banking centres. As a result, with the international banking market drying up, interest income from interbank lending has been weak since the third quarter of 2007. Financial institutions will "mechanically" incur capital losses on their portfolios of long-term financial investments. Accordingly, net provisions by Luxembourg banks were up sharply at 31 December 2007.

\section{Developing the financial centre's competitive advantages}

9. The development of the financial sector in Luxembourg depended historically very much on creating tax advantages and an ability to secure a regulatory "first-mover" advantage (Box 3). However, the tax advantages are increasingly being phased out. Thus, the future development of the financial sector's three main activities (private banking, investment funds, and financial engineering) will depend very much on the continued development of the regulatory framework in Luxembourg. Moreover, tax regulation will need to be updated in response to the phasing out of tax advantages. In the following, the competitive advantages of these activities are discussed in some details.

\section{Box 3. A brief account of Luxembourg's ascent as a financial centre}

Luxembourg began its ascent as a financial centre in the early 1960 s by syndicating international loans. With the introduction of Interest Equalisation Tax in the United States in 1963 discouraging issues of international loans on the New York financial market, the big American banks at the time sought to set up a capital market in Europe. As other financial centers, such as London, Zurich and Amsterdam, had more restrictive regulation at the time, the banks opted for Luxembourg which, as of the late 1920s, had introduced banking legislation that was a lot less restrictive than in the majority of other countries. As a result, Luxembourg turned itself into a centre where international Eurodollar issues were quoted and deposited, the City of London for its part specialising in issues. It was then that an increasing number of banks began to set up in Luxembourg, the trend becoming more marked as of 1967 with the huge influx of Scandinavian and German banks seeking, inter alia, to take advantage of the absence of compulsory reserve requirements.

7. Non-interest income accounts for $55 \%$ of total bank revenue, and institutions other than banks are also active in transactions closely tied to international stock market.

8. Testing for the nonlinearity of the relationship between bank income and stock market development and for the possible presence of multiple regimes in their joint evolution tend to perform better than a linear model (Annex A). In addition, a regime change is confirmed by the statistical tests. A first regime spans the period 1994-1998/1, for which the correlation obtained is higher (correlation coefficient: 0.89) than for the second regime (0.26), from 1998/2 until 2007/3, which includes the phase with sharper variations. This econometric measurement mitigates the conclusion of a strong dependence between bank income and stock market performance, although it does not cast doubt on the existence thereof.

9. CSSF press release of 18 January 2008 on provisional profit and loss accounts at 31 December 2007. 
The debt crisis in the Latin American countries in the early 1980s made it necessary to diversify this particular sector of activity. With neighbouring countries having relatively more restrictive tax policies in place, private banking expanded significantly in Luxembourg from that decade on, especially because of the high level of confidentiality (associated with the strict bank secrecy rules in place). The rapid transposition of directives, which can be described as a "first mover advantage", also enabled Luxembourg to develop an international market for investment funds. At the same time as it was building up financial activities involving individual clients, Luxembourg was establishing a position in the financial engineering business. With the legislation having allowed numerous different types of company providing financial packages to set up, Luxembourg became one of the prime sites for locating finance companies.

\section{Private banking and attracting private client business}

10. Private banking and asset management in Luxembourg began to develop in the early 1980s thanks to foreign customers taking advantage of Luxembourg's legislative framework, i.e. long-established strict banking secrecy rules (Article 458 of the Criminal Code) and non-taxation of non-residents' income from savings. With the Luxembourg authorities' co-operation in tax matters being subject to the principle of double incrimination, foreign savers were able to use the Luxembourg framework for tax purposes. ${ }^{10}$ Bearer bonds were at the time extensively held by foreign clients, who were not necessarily clients of the banks where the bonds were received. Subsequently, banking institutions increasingly developed structured products to expand their clientele, beginning with bearer SICAVs (see below) in particular, and then with other more sophisticated investment funds. Tax rules in this area were changed with the European Directive on taxation of savings, which came into force on 1 July 2005 and which was designed to harmonize savings tax mechanisms (by ensuring that capital income from individual's savings was taxed in the country of origin) while leaving each country free to set its own rate for its residents. ${ }^{11}$

11. Luxembourg (together with Austria and Belgium) secured agreement that they would not apply the Directive's automatic exchange of information, but they would introduce a withholding tax on income from certain products. The rate of this tax was set to gradually to increase: $15 \%$ until 1 July 2008, $20 \%$ until 1 July 2011 and $35 \%$ as of that date. $75 \%$ of the tax collected goes to the saver's country of residence, while the remaining $25 \%$ goes to the country collecting the tax. Withholding tax, not in full discharge, is a transitional measure and will eventually be replaced by automatic exchange of information subject to the condition that a number of other countries apply equivalent measures. With negotiations set to resume in 2011, the Luxembourg authorities have ensured that banking secrecy will be maintained at least until that date, although in the wake of the Liechtenstein tax scandal there have been calls for an early review of the Directive. Some of the clauses in the agreements are crucial: only fixed-income products are concerned and only private individuals are liable, and life insurance contracts are excluded. As a result, financial professionals believe that associated capital outflows have mostly been confined to small savers and that savings have been redirected via simple interest rate products into more sophisticated, higher value-added products, which are not liable to withholding tax. These include structured products (capital secure,

10. Where mutual legal assistance is concerned, some countries apply the double incrimination principle. For mutual assistance to be given to the requesting country, it must be established that the act that is the subject of the inquiry would be a criminal offence under the law of the requested country if it were to occur in that country. Where tax matters are concerned, Luxembourg and Switzerland have been identified (OECD, 2003) as countries in which a restrictive definition of tax evasion, combined with the application of the double incrimination principle, substantially limits the possibility of exchanging information in tax cases of a criminal nature with the vast majority of OECD countries.

11. Under these new regulations, every Member State has to inform its European partners of the amount of interest paid by a financial institution domiciled in its territory to non-residents from the European Union. This is the automatic exchange of information principle; on the basis of this information, non-resident (European) savers are taxed in their country of residence on their interest income from abroad. 
indexed or optional) and specific investment funds, such as hedge funds, real estate funds, venture capital funds, etc.

12. Another recent development is that personalised management is turning towards "top-of-therange" types of product, including family office. Drawing on the Swiss experience, family office is a form of private wealth management designed to achieve tax optimisation, in which the bank provides a wide range of services for its wealthy clients - usually members of the same family. These product developments in private banking have sustained growth in the sector, where deposited assets rose by $60 \%$ between 2003-07 (Weimerskirch and Flatter, 2007). ${ }^{12}$ Another fast-growing product type is Free Provision of Services (FPS) life insurance. This product is not subject to withholding tax and is aimed at non-residents from EU countries. Premiums issued via FPS presently account for almost $95 \%$ of premiums issued by Luxembourg life insurance companies, accounting for nearly half of all FPS life insurance contracts in the European Economic Area. Since the assets in life insurance contracts are frequently invested via investment funds, the existence of a large number of fund promoters has helped to develop the life insurance sector (qualified professionals, underlying investment vehicles, etc.). Similarly, in the framework of private banking, insurers distribute contracts to institutional clients (banks) which in turn use them to structure client assets, making insurers the suppliers of bank inputs. This development has been furthered by the regulatory freedom with respect to underlying assets and by the insurance sector being subject to the banking secrecy law.

\section{The investment fund sector}

13. The investment fund industry grew as the result of the introduction of new legislation. In early 1980s the Luxembourg authorities became aware of the European Directive draft regulating funds and their distribution, inducing them to introduce a law in 1983 to promote the development of such investment vehicles. Two years later, the UCTIS 1 (Undertakings for Collective Investments in Transferable Securities) directive came into force as the first Directive to regulate a financial product at European level providing them with a "European passport." The directive was transposed into Luxembourg law in $1988 .{ }^{13}$ For a few years, Luxembourg was the only EU country to provide investment funds authorized on its territory with the European passport. As a result, numerous promoters, whether from EU countries or not, domiciled their funds in Luxembourg so as to be able to market their fund shares on other Member countries' markets. Banks acting solely as depository institutions appeared, as did auditing companies, corporate auditors, companies specializing in the publication of reports, transfer agents, and other supporting services. This concentration helped to generate a body of expertise enhancing Luxembourg's attraction to promoters, creating a pole of excellence within Luxembourg banks, and securing Luxembourg a place as the second most important international promoter of investment funds (in terms of managed assets) behind the United States and followed by France.

14. The investment fund sector has benefited from other regulatory changes. In 1999, Luxembourg was the first country in Europe to pass legislation on international pension funds. The legal framework provides for the creation of two financial vehicles able to accommodate defined benefit or defined contribution funds on behalf of international industrial or commercial firms: SEPCAVs (open-ended

12. Over the period 2003-07, the average amount of assets per client rose by $28 \%$ to EUR 1 million, while portfolios of over EUR 10 million constituted the fastest growing segment. At the same time, banks with average assets per client in excess of EUR 1 million had a profitability that was twice the size of their competitors with smaller clients.

13. In 2002, the government transposed the UCITS 3 Directive, extending the range of products with the European passport to include more complex and risk-oriented products for strategic investment purposes. Product innovation introduced a range of new investment vehicles, such as multiple compartment funds; funds of funds; capital guaranteed or protected funds; click funds; redistributive funds; dedicated funds, etc. 
pension savings companies) and ASSEPs (pension savings associations). ${ }^{14}$ This legislation is separate from the legislation governing pension funds for domestic employees. A recent European Directive (2003/41/EC) (transposed into Luxembourg law in 2005) brought in a Community legal framework for pan-European pension funds. This allows multinational firms located in different European Union countries to set up a single pension fund with which to manage various pension plan assets in other EU member countries. However, industry sources consider it unlikely that these pan-European funds will develop on a large scale because of tax and regulatory obstacles. In February 2007, a Law on Specialised Investment Funds (for professional clients) introduced (for the covered funds) a reduced rate of subscription tax and investment rules that are more flexible than in the case of conventional funds, making them particularly attractive for alternative, hedge fund-style management.

\section{Financial engineering}

15. In 2007, a new form of finance company was introduced - the private asset management company or Société de gestion de Patrimoine Familial (SPF) - to replace the so-called 1929 holding legislation (H29). ${ }^{15}$ The tax regime applying to SPFs is essentially the same as in the case of H29 companies (no tax on dividends paid, no municipal business tax or net wealth tax, liability to the capital duty tax (droit d'apport) of $0.5 \%$ (which will be abolished in 2009) and to the yearly subscription tax of $0.25 \%$, no access to double taxation treaties, etc.). However, SPFs are available only to private individuals (or intermediaries acting in the interests of an individual or a group of individuals) and their sole purpose is the administration and management of financial assets, excluding any form of commercial activity. The restriction to private individuals should make the SPFs compliant with European State aid rules. Other legislative changes were already implemented in 1990 to allow setting up so-called SOPARFIS (Sociétés de Participations Financières) to remedy the limitations of the 1929 holding company as an international financial engineering vehicle. They are ordinary commercial companies not liable to the restrictions applying to company aims and not benefitting from tax exemption on profits. A SOPARFI can therefore pursue all the activities open to SPFs, but can also have an activity related to the management of its participations (advice on management, financing, real estate, etc.) or any other commercial or industrial activity. One advantage for foreign investors of this type of company is to repatriate investments in foreign companies /subsidiaries to the company in Luxembourg and become subject to Luxembourg's tax rules, with the aim of distributing the investment income to shareholders. As a consequence of being fully liable to tax, the SOPARFIs benefit from double-taxation treaties and the parent-subsidiary directive. A common tax regime for the parent company and the subsidiary allows distributed dividends to be tax-exempt (and in some cases also from withholding tax) in the country where the parent company is located. ${ }^{16,17}$ Taxation of

14. SEPCAVs are based on the American model, i.e. only the subscriber's contribution is set in advance, the capital paid out in the end depending solely on the results achieved by the asset managers. ASSEPs work on the defined benefit principle, i.e. the European model. In the majority of cases, the final payment is defined in advance, contributions being set in such a way as to cover requirements when the time comes to pay the supplementary pension.

15. The 1929 holding (H29) was a vehicle for holding capital and enjoyed a favourable tax regime, in return for which its range of activities was confined to taking participations in other companies, managing bond loans, and managing patents and licences under certain conditions. The holding was not allowed to engage in any commercial activities, failing which it would forfeit its tax regime. In 2006 the European Commission found the new H29 tax regime to be non-compliant with European legislation on State aid, leading to the government decision to phase out the scheme by 2010. H29s were excluded from double taxation treaties and were not allowed to benefit from the tax regime common to parent companies and their subsidiaries resident in the European Union. This characteristic therefore restricted the use of $\mathrm{H} 29 \mathrm{~s}$ as vehicles in international acquisition structures. These structures were in fact mainly used by private individuals as wealth management products.

16. The exemption from withholding tax applies to the dividends if the following conditions are fulfilled: $a$ ) the subsidiary is a collective entity that is a fully taxable resident (in particular a resident taxable stock corporation); $b$ ) the parent is a fully taxable collective entity that is a resident of Luxembourg, a resident 
SOPARFIs is very light and there is no withholding tax on distributed income in the condition outlined in endnote 15 are fulfilled. ${ }^{18}$ Many private equity funds in the European Union go through a Luxembourg SOPARFI - being examples of how Luxembourg's financial sector has benefitted from continuous adaptation of the tax and regulatory framework.

16. Two other financial innovations were introduced in 2004. SICARs are vehicles to promote venture capital funds and their private equity investments, allowing the financial sector to seek a foothold in a market in Europe, which hitherto has been dominated by London. A SICAR is a structure which has many functions similar to an investment fund, but is not subject to any restrictions in terms of portfolio and investment policies. The legislation was introduced to provide a regulatory framework (previously such funds were completely unregulated) to make such vehicles attractive for investors (banks, insurance companies, pension funds) wanting to work in a more regulated and more transparent framework. Similar products already existed in other countries but, as in the case of SOPARFIs, the advantage of Luxembourg lies in the legal safety and associated tax benefits. ${ }^{19}$ The other innovation was a legal framework for securitisation vehicles in Luxembourg, as in other countries such as France, Belgium, the Netherlands and the United States. ${ }^{20}$ The banking sector uses securitisation to make certain illiquid claims stemming from credits granted more liquid. Securitisation can provide a more flexible and less onerous source of financing than traditional credits, particularly since a great many assets can be securitised. The securitisation vehicle, which can be set up in the form of a securitisation company or fund, finances acquisitions by issuing nominative or bearer securities representing the share portfolio. These securities, which tend to be reserved for institutional investors, give access to an almost unlimited variety of products allowing optimum

company of the EU whose legal form falls within the scope of Article 2 of the Parent-Subsidiary Directive, a permanent establishment of a company that falls within the scope of Article 2 of the Parent-Subsidiary Directive, a domestic permanent establishment or a stock corporation resident of a state with which Luxembourg has concluded a double tax treaty, a Swiss resident capital company that is subject to corporate income tax without benefiting from a tax exemption; $c$ ) the parent has held, or commits to hold, during an uninterrupted period of at least 12 months, a shareholding of at least $10 \%$ in the capital of the subsidiary or of a purchase price of at least EUR 1200 million.

17. The tax exemption depends on the parent company being a joint stock company resident in Luxembourg and holding or having held for a minimum of 12 months a minimum participation amounting to $10 \%$ in the capital of the subsidiary or totalling EUR 1250 million. The subsidiary has for its part to be a resident or foreign company liable to comparable income tax.

18. SOPARFIs are only liable to the capital duty tax of $0.5 \%$ when setting up, a flat rate minimum wealth tax (EUR 62 for a limited company and EUR 25 for a limited liability company), and VAT on operating costs.

19. No capital contribution tax, but a fixed charge of EUR 1250 ; exemption from wealth tax; benefits from the parent-subsidiary privilege; the income from transferable securities (dividends, capital gains, liquidation profits, etc.) are exempt from Luxembourg income tax; dividend distributions to investors are completely exempt from withholding tax, whether the investors are resident or not, are natural or legal persons or not, are EU residents or not, come from a country with which Luxembourg has signed treaties or not; non-residents are exempt from Luxembourg income tax with respect to income from holding SICAR shares; SICAR managers are exempt from VAT. On the other hand, the European Private Equity and Venture Capital Association notes in its 2006 annual report that, compared to SICARs, few tax incentives have been introduced for R\&D expenditure and technology transfers by young innovative firms (Indicators of Tax and Legal Environments Favouring the Development of Private Equity and Venture Capital and Entrepreneurship in Europe, Dec. 2006).

20. Securitisation is the process by which a company or a natural person transfers certain assets to a securitisation vehicle so as no longer to assume the management risk involved. Assets that can be securitised include trade receivables, mortgages, current accounts, shares, debenture loans, any financial asset, any immovable asset, which are all characterised by having a certain value or a future income stream. 
diversification of the portfolio. Like other investment vehicles, securitisation vehicles enjoy a favourable tax regime and the regulatory definition of assets that can be securitised is very broad.

\section{Intersectoral effects, location and employment}

17. Underpinning Luxembourg's banking and financial system is a capacity for continuously adjusting the regulatory and tax framework. Once favourable conditions have generated competitive advantages, the question arises as to how to ensure that the development of financial activities maintains a lasting momentum. Endogenous forces, for example, can contribute to the emergence of a cluster around a financial activities centre. At the same time, and in a context of intense economic integration, the dynamics of a financial centre raise the issues of out-sourcing and other changes in the financial industry production chain. For a small economy, such questions cannot be separated from the various aspects of attracting and developing talent.

18. A number of spillover effects can be identified. ${ }^{21}$ Knowledge spillovers derive from the proximity of actors wanting to exchange complex information that is difficult to codify, and where exchanging and comparing localised information constitutes an important source of financial innovation (Taylor et al., 2003). Labour market spillovers (labour market pooling) in a financial centre exist as a result of the concentration of staff specialised in handling economic and financial information. The location spillovers are derived from the purchases of a financial pole of inputs, encouraging the setting up and development of intermediate industries and services located upstream: accounting, legal services, consultants, recruitment, publications and information, computer services, etc. Econometric investigation of these external effects for the financial sector and other service sectors shows that a $10 \%$ increase in activity in the financial service sector induces $2.8 \%$ higher activity in the business-service sector (and $1.6 \%$ higher activity in the non-financial market service sector), excluding the financial sector's direct purchases in the business service sector (Bourgain and Pieretti, 2006). ${ }^{22,23}$ These results are evidence of an important self-sustaining process that helps to perpetuate the financial sector's activities.

19. There are no precise surveys to judge the extent of outsourcing from the financial sector, but Deloitte Research (2004) claims that by 2008 the world's hundred leading financial establishments would have moved activities accounting for $15 \%$ of their total costs to the developing countries (LDCs) in the Indian Ocean area. The same survey indicated that $67 \%$ of financial service companies had resorted to outsourcing in 2003. The main reason for outsourcing activities is to benefit from reduced labour costs, which in financial services amounts to more than two-thirds (Gordon et al., 2005). New technology in the form of secure means of data transmission has enabled the outsourcing of back office services, which account for a large proportion of the activities of Luxembourg's financial centre (mainly accounting, settlement and clearance). Moreover, these operations are considered to be the most separable of the other functions in the banking production chain. Because of electronic transaction and straight-through

21. The New Economic Geography literature identifies two significant centripetal forces: technological spillovers and pecuniary spillovers (M. Fujita, P. Krugman and A. Venables, 1999; Fujita and Thisse, 2002; and Scitovsky, 1954).

22. The approach follows Midelfart-Knarvik and Steen (1999), which is based on the work by Caballero and Lyons (1990).

23. In the other direction, the effects from a similar sized shock in the business sector and the IT sector on the financial sector are $1.8 \%$ and $2.3 \%$, respectively, which is probably related to lower intermediate input prices relative to the prices of financial services and a diversification of inputs in the financial sector. 
processing (STP), a transaction can be performed automatically and forwarded anywhere without any human intervention. ${ }^{24}$

20. The general forces behind outsourcing have limits and drawbacks specific to banking and financial activities. The information intensity of numerous activities in the production chain remains significant - and not solely vis-à-vis clients. Banking and financial centres are places where complex information is handled, which it is difficult to transmit remotely (Gehrig, 2000) And face-to-face contact is all the more crucial when the information is imperfect, always changing and hard to codify, which is the case of a lot of financing activities which are dependent on relations of trust. The geographical fragmentation of the banking and financial production process is also liable to increased operational risk related to internal procedural, personnel or systemic failures. In the Basel II agreement, the supervisory authorities are placing ever increasing emphasis on this type of risk. Fear of seeing operational risks increase as a result of externalisation is cited by $40 \%$ of the European banks surveyed (Pujals, 2005). With respect to Luxembourg more specifically, fear of confidentiality not being respected is a factor that inhibits outsourcing.

21. As regards the possibility of "moving-up" the production chain, Luxembourg has certain handicaps. The Luxembourg centre does not host front-line financial centre activities and headquarters. In particular, there are very few investment banks located in Luxembourg. Because of its modest size, the city of Luxembourg is not as attractive to top investment fund managers and other talent as the major European and North American cities. On the other hand, the sector specific knowledge in administration, domiciliation and depository bank activities could form the basis for moving up the production chain in stages. Using the existing structures (conventional funds), asset management in Luxembourg is beginning to move towards more complex products (private equity, SICARs, hedge funds) taking advantage of the fact that middle- and back-office operations for such products are already performed in Luxembourg. This first step could serve as the basis on which to develop risk management and asset management activities, although such a move is particularly demanding in terms of qualified human resources. In this respect, financial institutions in Luxembourg have to compete with the salaries (and non-pecuniary benefits associated with location) paid in capitals such as London, New York and Dublin if they are to attract more experienced staff. In this respect, it is important to implement the proposals to make working permit and visa rules more flexible and less bureaucratic (Box 4). This constraint with regard to attractiveness and skilled human resource training must not be underestimated when considering product differentiation strategies and, more generally, the development of innovative activities.

\section{Box 4. Rules and regulation for foreigners in Luxembourg}

The current rules for employing workers from outside the EU are complicated and time consuming and governed by a 1972 law. Workers from outside the EU must obtain a work permit before applying for a residence permit. Moreover, a labour market test is in place (as in other EU countries) where employers have to advertise their vacancy at the labour office (Administration pour l'Emploi - ADEM) and proves they were unable to find anyone in the EU to fill the position. Requests for new work permits and renewals must be submitted by the employer. The requests are transmitted by the ADEM to a labour market commission for an opinion statement, while the final decision is taken by the Ministry of Immigration. Once a request is granted, the applicant can apply for a visa at a Luxembourg Embassy. There are four different types of work permits in place: Type A (valid for one year, one profession, and one employer); Type B (valid for four years, one profession, and any employer); Type C (valid for five years, all professions, and any employer); and Type D (for traineeships).

24. The loss of a competitive tax or regulatory advantage can induce outsourcing. Recently, some of Luxembourg's tax advantages appeared vulnerable to international pressure. The European Union has agreed in 2007 that VAT should be collected on services in the countries where they are consumed. This new regime (coming into force in 2015) may jeopardize the location in Luxembourg of subsidiaries of Internet operators such as eBay and Amazon. 
Entrepreneurs are exposed to even greater hurdles. Entry is permitted upon the presentation of the following documentation: professional qualification certificate; visa; a Luxembourg trade authorization; a certificate copy of the statutes of their company; a copy of the travel ticket; a bank guarantee of euro 12350 per family member from a bank approved in Luxembourg and deposited in favour of the Ministry of Foreign Affairs Moreover, such entry permits are only valid for one year and can only be renewed if the enterprises generates sufficient revenue.

To obtain a residence permit the applicant must present an application at the local municipality containing the following documentation: valid travel document; certified copies of the work permit, birth and marriage certificates; job contracts or other justification of means of existence; medical certificate (including a radiological exam); justification of adequate housing (rental contract); and criminal records or "good moral" certificates. In general the duration of the residence permit does not exceed that of the working permit.

The government has presented a draft law to parliament to simplify work and entry permits for workers and entrepreneurs. In the proposal, work and residence permits are merged into one permit and applications have to be initiated by the workers, but the labour market test remains in place. In addition, the proposal incorporates European Law's notion of a Community preference, whereby applicants from the EU will receive preferential treatment. An additional element is that special residence permits for highly skilled workers and scientists are envisaged.

Double nationality is presently not permitted in Luxembourg, but foreigners can become nationals on the conditions that they were born in Luxembourg; or are married to a Luxembourger; or had compulsory schooling in Luxembourg. The conditions that have to be fulfilled include; residency in Luxembourg during the past year and for at least five consecutive years; relinquishing the nationality of origin; some knowledge of at least one of the three official languages and a basic knowledge of Luxembourgish.

A law proposal is opening up for the possibility of having dual citizenship and is redefining the criteria for acquiring Luxembourg nationality to include: residency of at least seven years; a knowledge of institutions and fundamental rights in Luxembourg (including following special courses); a sufficient knowledge of spoken Luxemburgish; and an honorability condition that specifies that candidates cannot have been condemned to prison sentences of more than two years.

\section{Development of the financial centre: challenges and strategies}

22. The high reliance on the financial sector is a concern as it makes the economy vulnerable to external shocks and eventually international competition may remove the comparative advantages of placing financial institutions in Luxembourg. Yet, implementing a diversification strategy is not easy for a small economy, for obvious reasons of demand (limited home market size) but also because of limited resources (Armstrong and Read, 1998; Easterly and Kray, 2000). ${ }^{25}$ Moreover, the relatively limited potential in terms of productive resources means that a small economy cannot go for all-out expansion of very varied sectors of activity (extensive inter-branch diversification). In view of these constraints, an "intra-industry" diversification could offer the economy some protection against external shocks. ${ }^{26} \mathrm{Such}$ an approach offers the advantage of consuming fewer resources, because it is rooted in an existing pillar of the Luxembourg economy. Moreover, such a strategy also carries less risk, because it is based on a high degree of specialisation and not on hazardous industrial-policy choices. For instance, the considerable growth of investment-fund administration did not stem directly from an entirely external choice, but rather from a skilful shaping of the national legislative and regulatory framework in response to shifting international financial trends. But a dynamic intra-financial industry diversification strategy hinges on the potential for adjustment and innovation on the part of financial-market players, which depends both on internal market forces and on conditions outside the market (such as the education system and Luxembourg's attractiveness for talent).

25. The high export-intensity of an economy that lacks a domestic market opens the door to economies of scale, but such a strategy could be risky given the potential exposure of the sector's competitive advantages to international upheavals. Indeed, there is a highly robust inverse relationship between an economy's size and its business-cycle volatility (Furceri and Karras, 2008).

26. "Diversification" is used here to signify a shift towards lesser correlation between respective income from the activities in question. 
23. For an intra-industry diversification strategy to be successful, it must be assured that there are no bottlenecks in terms of human resources. This requires that the capacity to attract foreign human resources remains in place and that the education system can provide necessary qualifications to a sufficient number of graduates. Currently, the latter seems quite unlikely, as only 500 students (15\% of total enrolment) at the University of Luxembourg are enrolled in studies of Economics, Management and Finance and in the private Luxembourg School of Finance (under the University of Luxembourg) the enrolment is only 32 graduate students (of which very few are Luxembourgers). A contributing factor might be a tuition fee of Euro 17 500. The constant increase in cross-border workers is likely in the medium term to require considerable investments in transport infrastructure. Moreover, foreign workers will only settle in Luxembourg if the quality of life is sufficiently good. This requires well developed public policies in areas such as infrastructure investments, housing policies, and the provision of high quality public goods and services (including education and health services).

24. Such measures to improve the attractiveness of working in Luxembourg have to be tailored to various non-resident groups. Maintaining a steadily increasing inflow of cross-border workers will depend on expanding transportation infrastructures as recommended recently in the OECD Territorial Review of Luxembourg (2008) (Annex 2.A2). Attracting high-skilled talent from outside the European Economic Area is hampered by the current strict and bureaucratic working permit and visa rules. As planned, making these rules less bureaucratic and more flexible will allow them to better reflect labour market needs. Likewise, allowing dual nationality with less strict language requirements, such as only requiring knowledge of one of the official language, would make it more attractive for talented individuals to make long-term commitments in Luxembourg. Alternatively, talent could be developed locally, but this requires that the education sector aims more at fulfilling labour market demands, including bolstering higher education in finance and other areas of interest for the financial sector.

25. The provision of high quality services should also include the strategic role of the legislative and regulatory framework for the financial sector. ${ }^{27}$ A financial centre such as Luxembourg, which has almost no local market and is highly integrated in the European economy, is forced to make more of a competitive effort to secure higher returns and lower taxation than its major competitors. Where banking and finance are concerned, regulations can provide part of the measures to address distortions in (asymmetric) information and to protect savers' rights of ownership. In addition, a financial centre's guarantee of stability is appearing more and more to be the key issue to its attractiveness. The forming of the legislative and regulatory framework must take place within the context of the international regulatory context and the pressures that it generates, especially from the point of view of investor protection and information and risk management, including operational risk. So the response to regulatory constraints can result in a qualitative "best value", rather than in minimalist strategies.

26. With the Basel II Accord, there is a move towards prudential regulations based on prevention of the main financial risks, as regulatory capital requirements are more closely aligned with the underlying risks that banks face. It would seem that the regulatory authorities are gaining a degree of independence with regard to assessing what is needed in terms of protecting against risks and so can differentiate themselves in relation to the minimum level. ${ }^{28}$ These international rules could tempt so-called offshore centres to opt for a minimalist strategy or even seek to circumvent them. A "best value" strategy, on the

27. The role of the institutional and regulatory framework as a factor of attractiveness is admittedly not peculiar to the financial sector (Glaeser et al., 2004), but it does seem stronger in that context with financial activities being so dependent on saver and investor confidence.

28. For example, the Directive 2005/60/EC of the European Parliament and of the Council of 26 October 2005 on the prevention of the use of the financial system for the purpose of money laundering and terrorist financing draws directly on the "know your customer" principle drawn up by the Basel Committee, recommends adapting anti-laundering systems to customer types in order to gain in efficiency (BIS, 2003). 
other hand, can act as a means of differentiation by accentuating the guarantees given to the investor with respect to the security of his assets, transparency as regards how funds are invested, monitoring possibilities, etc. All of these characteristics of contracts (guaranteeing of property rights and giving savers greater security) help to reduce risk and the information asymmetry problems to which remote investors are especially sensitive. This concern is particularly obvious in the new investment funds sector (venture capital, private equity, etc.). In the context of this strategy, taxation is more the price to be paid for gains in terms of risk reduction and having fewer information problems. The European Union's MiFID Directive in the financial sector provides a recent example of this "best value" possibility ${ }^{29}$ In this connection, industry sources in Luxembourg's banking sector point out that compliance is not necessarily a burden, but instead can be used to create a decisive competitive advantage (Pitton, 2007). The advantages for private individuals and "small" investors include a better quality and bigger range of services and products (including tailor-made services) while providing for a much higher level of protection.

27. The legislative and regulatory adjustment process has been a key factor in the financial innovation process in Luxembourg. It stems from a process of legal and regulatory engineering involving collaboration between the public authorities and financial-sector professionals aimed at shaping the development of new products. So far, these efforts have mostly arisen from external pressures, but their general aim is to create the sort of conditions that will prove conducive to the emergence of new products and new activities. This shared interest has to be viewed in the context of international competition between locations, where authorities seek to adapt their institutional frameworks to attract mobile international clients and resources. In this context, analysis of the size of different economies (especially Streeten, 1993; Easterly, W. and A. Kray, 2000) shows that, despite major handicaps inherent in being small, there is a natural source of institutional comparative advantage deriving, in particular, from there being more consensus in favour of change and adjustment and fewer impediments to public decision making. Where Luxembourg's financial centre is concerned, venture capital funds, the law on securitisation and pan-European pension funds are examples of this sharing of innovation between the public authorities and private players. But such complementary efforts must be sustained and not occasional. They require that the public authorities put in sufficient institutional and human resources, which is justified in terms of their likely effect on tax revenues.

28. The main challenges for maintaining a dynamic financial sector are to maintain and expand the attractiveness of investing and working in Luxembourg. Preserving the attractiveness of investing in Luxembourg depends on the continued good supervision of the sector. In this respect, the special study by the financial supervisory authority (Commission de Surveillance du Secteur Financier) on the potential exposure of financial institutions to (subprime) mortgage-related risk was an important step in reassuring market participants. The authorities should continue to foster financial soundness by continuous adaptation of their careful regulatory framework - for example in compliance with the Basel II agreement to adopt more prudential regulations to safeguard the reputational attraction of the financial sector - and pursue their quest for financial stability by repeating such exercises at regular intervals as well as fostering greater transparency about the situation of the financial system. A summary of policy recommendations can be found in Box 5.

29. Markets in Financial Instruments Directive which came into force on 1 November 2007. Over and above the objective of harmonising the rules governing investment services and the exercise of investment activities (with the introduction of a single passport at European Union level), the Directive is designed in particular to improve investor protection through the application of a whole series of formalities and to comply with criteria regarding transparency and the information to be given to clients. 


\section{Box 5. Summary of policy recommendations for the financial sector}

- To foster financial soundness, the authorities should continue to improve their regulatory framework, for example in compliance with the Basel II agreement to adopt more prudential regulations to safeguard the reputational attraction of the financial sector.

- The special investigation on subprime mortgage assets was welcome, and the supervisors should pursue their quest for financial stability by repeating such exercises at regular intervals as well as fostering greater transparency about stability of the financial system.

- To facilitate a growing number of cross-border workers, transport infrastructures should be expanded further.

- To attract highly-skilled international talent, immigration laws for non-EU workers should, as planned, be made more flexible. In addition, the current proposal to allow dual nationality should be implemented, but the strict language requirement should be eased to only requiring knowledge of one of the official languages.

- To develop highly-skilled talent locally, the education sector should aim more at better meeting labour market demands, including bolstering higher-education in finance and other areas of interest for the financial sector at the University of Luxembourg. 
ECO/WKP(2009)1

\section{BIBLIOGRAPHY}

Armstrong H.W. and R. Read (1998), "Trade and Growth in Small States: the Impact of Global Trade Liberalisation", World Economy 21(7), 563-85.

Banque centrale du Luxembourg (2003), Bulletin de la BCL, 2003/1.

Banque centrale du Luxembourg (2007), Annual Report, 2006.

BIS (2003), Basel Committee on Banking Supervision, The compliance function in banks, Consultative Document, October 2003.

Bourgain, A. and P. Pieretti (2006), "Measuring Agglomeration Forces in a Financial Center", Economics Bulletin, 18, No. ${ }^{\circ}$, 1-9.

Caballero, R.J. and R.K. Lyons (1990), "Internal versus External Economies in European Industry", European Economic Review, 805-830.

Deloitte Research (2004), “The Titans Take Hold”, Report, May, www.deloitte.com.

Easterly, W. and A. Kray (2000), "Small States, Small Problems? Income, Growth, and Volatility in Small States", World Development, 28 (11), 2013-2027.

Fujita, M., P. Krugman and A.J. Venables (1999), "The Spatial Economy: Cities, Regions, and International Trade", MIT Press.

Fujita, M. and J.F. Thisse (2002), “Economics of Agglomeration”, Cambridge University Press, Cambridge.

Furceri, D. and G. Karras (2008), "Business Cycle Volatility and Country Size: Evidence for Sample of OECD Countries", Economics Bulletin, Vol. 5, No. 3:1-7.

Gehrig, T. (2000), "Cities and the Geography of Financial Centers", in J. Thisse and J.M. Huriot (eds), The Economics of Cities: 415-445, Cambridge University Press.

Glaeser, E., R. La Porta and F. Lopez-De-Salinas (2004), “Do Institutions Cause Growth", Journal of Economic Growth, 9:271-303.

Gordon, I., C. Haslam, P. McCann and B. Scott-Quin (2005), "Off-shoring and the City of London", Corporation of London, Business School for Financial Market, March.

Lehmann, H. and M. Manz (2006), “The Exposure of Swiss Banks to Macroeconomic Shocks - An Empirical Investigation", Swiss National Bank Working Papers, 2006-4.

Midelfart-Knarvik, K.H. and F. Steen (1999), "Self-Reinforcing Agglomerations? An Empirical Industry Study", Scandinavian Journal of Economics, Vol. 101, No. 4:515-532. 
OECD (2003), "Improving Access to Bank Information for Tax Purposes: 2003 Progress Report”.

OECD (2008), OECD Territorial Review of Luxembourg.

Pieretti, P., A. Bourgain and Ph. Courtin (2007), Place financière de Luxembourg, Analyse des sources de ses avantages compétitifs et de sa dynamique, de Boeck.

Pitton, D. (2007), Innovation dans le conseil en investissement : la Compliance est une opportunité de se créer un avantage compétitif, Le Mensuel d'AGEFI, November 2007.

Pujals, G. (2005), Délocalisations et externalisations dans le secteur financier, Revue de l'OFCE:211-238.

Rouabah, A. (2006), La sensibilité de l'activité bancaire aux chocs macroéconomiques : une analyse en panel sur des données de banques luxembourgeoises, Working paper No. 21, Banque centrale du Luxembourg.

Schuller, G. (2005), Les investissements directs étrangers (IDE) : cadre conceptuel et application au Luxembourg, Rapport annuel 2004 sur la Compétitivité de l'économie luxembourgeoise, Cahiers d'Économie du Statec No. 98, Luxembourg.

Scitovsky, T. (1954), “Two Concepts of External Economies”, Journal of Political Economy, 62:143-151.

Statec (2008), Note de conjoncture 3-07, March.

Streeten, P. (1993), “The Special Problems of Small Countries”, World Development, 21(2):197-202.

Taylor, P. et al. (2003), “Financial Services Clustering and its Significance for London”, Report, Corporation of London.

Wampach, C. (2004), L'évolution de l'emploi bancaire au Luxembourg, Commission de Surveillance du Secteur Financier, Luxembourg, November.

Weimerskirch, P. and E. Flatter (2007), La banque privée a réussi sa révolution, Mensuel AGEFI, November. 


\section{ANNEX A. NONLINEAR MODEL OF THE RELATIONSHIP BETWEEN EUROPEAN STOCK INDEX/BANK INCOME AND REGIME-CHANGE DETECTION}

Figure 4 in the main text showed the varied trends for banking net income and European stock markets, suggesting different regimes for certain sub-periods.

One way to identify any such breaks in the series trend is to apply Chow tests; however, these tests assume both that the parameters of the model remain constant over time, and that break dates are known in advance. But structural change is an irreversible instability affecting process parameters, and when such changes in trend are present in the series, estimations made in this way may be specified incorrectly.

To remedy this deficiency, a sample is often cut into sub-periods on the basis of presumed break dates, but this method diminishes the sample, especially if the time series involved are very short. Moreover, in most cases structural changes can be recurrent and require another, more general type of model such as Markov's regime-change models (see Hamilton, 1989; and Krolzig, 1997 and 2001). The advantage of these models is that they require neither prior knowledge of break dates nor division of the period of the study. The generating model is that of Hamilton (1989), originally applied to quarterly GDP growth in the United States. Hamilton's (1989) univariate method was generalised to a switching vector autoregression (VAR) model so that multiple series subject to regime change could be modelled (see Krolzig, 1997).

Method: Nonlinear model

Hamilton's (1989) generating model is a fourth-order univariate autoregression model:

$$
\Delta y_{t}-\mu\left(s_{t}\right)=\alpha_{1}\left(\Delta y_{t-1}-\mu\left(s_{t-1}\right)\right)+\alpha_{2}\left(\Delta y_{t-2}-\mu\left(s_{t-2}\right)\right)+\cdots+\alpha_{p}\left(\Delta y_{t-p}-\mu\left(s_{t-p}\right)\right)+u_{t}
$$

with $u_{t} \sim \operatorname{NID}\left(0, \sigma^{2}\right)$.

The conditional mean $\mu\left(s_{t}\right)$ varies between two states,

$$
\mu\left(s_{t}\right)=\left\{\begin{array}{l}
\mu_{2}>0 \quad \text { si } s_{t}=2 \text { ('expansion', 'boom') } \\
\mu_{1}<0 \quad \text { si } s_{t}=1 \text { ('contraction', 'recession') }
\end{array}\right.
$$

The regime-generation process is assumed to follow a two-state Markov chain such that $p_{21}$ is the probability of transition from expansion to contraction and $p_{12}$ the probability of leaving the contraction regime for an expansion regime.

Hamilton's univariate method was generalised (see Krolzig, 1997) to the switching VAR model, noted MS-VAR. These multivariate models make it possible to model multiple series subject to regime changes. In the specifications for an MS-VAR model, all autoregressive parameters can be conditioned by state $s_{t}$ of the Markov chain. 
In Hamilton's univariate model as well as the subsequent multivariate models, the regime-generation process is an ergodic Markov chain having a finite number of states $s t=1, \ldots, \mathrm{M}$ which are defined by the transition probabilities:

$$
\mathrm{p}_{\mathrm{ij}}=\operatorname{Pr}\left(\mathrm{s}_{\mathrm{t}+1}=\mathrm{j} \mid \mathrm{s}_{\mathrm{t}}=\mathrm{i}\right), \quad \sum_{\mathrm{j}=1}^{\mathrm{M}} \mathrm{p}_{\mathrm{ij}}=1 \quad \forall \mathrm{i}, \mathrm{j} \in\{1, \cdots, \mathrm{M}\}
$$

More specifically, it is assumed that $\mathrm{s}_{\mathrm{t}}$ follows an ergodic Markovian process having $\mathrm{M}$ states with an irreducible transition matrix $\mathrm{P}$ such that:

$$
\mathrm{P}=\left(\begin{array}{cccc}
\mathrm{p}_{11} & \mathrm{p}_{12} & \cdots & \mathrm{p}_{1 \mathrm{M}} \\
\mathrm{p}_{21} & \mathrm{p}_{22} & \cdots & \mathrm{p}_{2 \mathrm{M}} \\
\vdots & \vdots & \ddots & \vdots \\
\mathrm{p}_{\mathrm{M} 1} & \mathrm{p}_{\mathrm{M} 2} & \cdots & \mathrm{p}_{\mathrm{MM}}
\end{array}\right)
$$

Where $\mathrm{p}_{\mathrm{iM}}=1-\mathrm{p}_{\mathrm{il}}-\ldots-\mathrm{p}_{\mathrm{i}, \mathrm{M}-1}$ for $\mathrm{i}=1, \ldots, \mathrm{M}$. This law can be used to infer how the regimes will evolve from the data.

These models can be estimated by the maximum-likelihood method based on the expectationmaximization (EM) algorithm discussed in Krolzig (1997). This estimation technique makes it possible to obtain autoregressive parameters as well as the transition probabilities governing the Markov chain of the unobserved states. If $\mathrm{OOO}$ stands for the vector of the parameters, in the Hamilton model, then $\mathrm{T}=\left(\mu_{\mathrm{s}}\right.$, $\left.\alpha_{1}, \ldots, \alpha_{4}, \tau_{2}, p_{11}, p_{12}\right)$. n. The parameter $\mathrm{OOO}$ is chosen to maximise the likelihood of observations $\mathrm{Y}_{\mathrm{t}}$.

Results of the estimation of the nonlinear VAR model:

We estimated the dynamic of the relationship between income (in Log and seasonally adjusted) "LSARev_net" and the European stock market index "Ldje_50" using this bivariate nonlinear model.

This estimation confirms the nonlinear nature of the relationship between the variables LSARev_net and Ldje_50, insofar as the log-likelihood of the nonlinear model (17.9555) is greater than that of the linear model (-21.7236). This nonlinearity justifies an estimation with regime change.

The results confirm a regime change in the joint evolution of the two variables and make it possible to distinguish and classify two main periods - Regime 1, stretching from 1994/4 to 1998/1; and Regime 2, from 1998/2 until 2007/3. These highly persistent regimes ( $p_{11}=0.9328$ and $\left.p_{22}=1\right)$ are illustrated by the figure below, which indicates the probability that each observation will belong to Regimes 1 or 2 .

The usual statistical tests (LR, AIC, HQ, SC) show that this model reflects the structure of the relationship between the two variables better than a linear model. The $M C$ matrix below shows that the strong correlation (0.89) between the two variables (LSARev_net, Ldje_50) during the first period declines in Regime 2 to only 0.26 .

$$
M C=\left[\begin{array}{cc}
L S A R e v_{-} n e t & 0.2599 \\
0.8922 & \text { Ldje_50 }
\end{array}\right]
$$


Model (LSARev_net, Ldje_50)

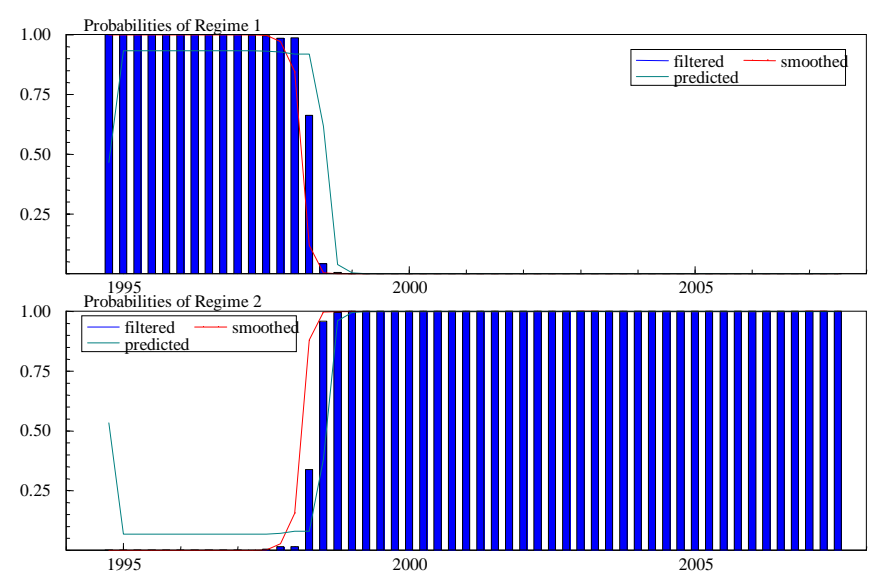

* We should like to thank F.B. Aka (CREA, Université du Luxembourg) for performing these calculations.

\section{BIBLIOGRAPHY}

Hamilton, J.D. (1989), "A New Approach to the Economic Analysis of Nonstationary Time Series and the Business Cycle", Econometrica, 57:357-384.

Krolzig, H.M. (2001), "Business Cycle Measurement in the Presence of Structural Change: International Evidence”, International Journal of Forecasting, 17:349-368.

Krolzig, H.M. (1997), "Markov Switching Sector Autoregressions. Modelling, Statistical Inference and Application to Business Cycle Analysis", Berlin, Springer. 


\section{ANNEX B. MAIN RECOMMENDATIONS IN THE OECD TERRITORIAL REVIEW OF LUXEMBOURG}

\section{Housing measures:}

- Extend monitoring and forecasting of land and housing markets to the "Greater Region" level so as to derive a better measure of the impact of this sector on cross-border traffic.

- Conduct an awareness campaign among local officials to ensure that national strategic priorities are taken properly into account in the PAGs.

- Restore expropriation for public purposes as an operational tool.

- Consider creating a public land agency with broad powers, endowed with the right of preemption.

- Create a true property tax to encourage sale of building lots.

\section{Commuting measures:}

- Harmonise fuel taxes so as to discourage foreign drivers from using their car in Luxembourg, where prices at the pump are well below those in neighbouring countries.

- Evaluate and explain the technical, financial and organisational means needed to achieve the IVL objectives, so as to contribute to integration of sector policies.

- Conceive the future master plan for infrastructure, using a multimodal concept and with quantified objectives, taking due account of truck traffic, which adds to congestion and is an important source of greenhouse gas emissions.

- Establish a multiyear financing schedule, following identified and integrated priorities.

- Take advantage of the national umbrella structure for transportation called for in the Master Programme to strengthen co-operation with adjacent regions by creating a supra-regional transport agency.

\section{Territorial planning measures:}

- Consolidate the role of the Centres of Development and Attraction, establishing an urban hierarchy around which the other municipalities can organise themselves. To this end, adopt a public investment policy that recognises each CDA's role in a given region.

- Continue and build upon the dynamics created by the co-operation agreements between the State and certain urban groupings (Southwest Luxembourg Metropolitan Area, Nordstad) and extend this approach to other territories (Capital Region Northwest, South Region). 
- Consider a regional map vying to achieve economies of scale, due to dimensions of the territory, by regrouping the smallest regions into a single region centred on the Nordstad.

\section{Mobilising human and financial resources:}

- To associate local elected officials more closely to the conception and definition of the abovementioned policies so as to facilitate their translation into urban planning decisions at the local level.

- To adequately consult associations and citizens, in particular since civil society plays an important role in the elaboration of urban planning documents. This would permit to situate the choices established around the PAGs in a wider context while facilitating the implementation of Public Private Partnerships (PPPs) contributing towards the implementation of the measures considered.

- To give priority to the mobilization of the means necessary for the deployment of these strategies. The staffing and budgetary means allocated to the Directorate for Territorial Planning (DATer), which assumes numerous inter-ministerial and "Greater Region" co-ordination tasks, do not seem sufficient for this purpose. New competencies from the University of Luxembourg could be called upon for this.

- To give a strong translation both in governance terms and in means, by establishing an inter ministerial fund with multi-annual financing, that would help to leverage the projects of a multi-sector character. 
ECO/WKP(2009)1

\section{WORKING PAPERS}

The full series of Economics Department Working Papers can be consulted at www.oecd.org/eco/Working_Papers/

659. Fiscal policy responsiveness, persistence, and discretion

(December 2008) António Afonso, Luca Agnello, Davide Furceri

658. The economics of climate change mitigation: policies and options for the future

(December 2008) Jean-Marc Burniaux, Jean Chateau, Romain Duval and Stéphanie Jamet

657. Maximising Mexico's gains from integration in the world economy

(December 2008) David Haugh, Roselyne Jamin and Bruno Rocha

656. How do taxes affect investment and productivity? An industry-level analysis of OECD countries (December 2008) Laura Vartia

655. Strategies for countries with favourable fiscal positions

(November 2008) Robert Price, Isabelle Joumard, Christophe André and Makoto Minegishi

654. Monetary transmission mechanism in Central and Eastern Europe: Surveying the Surveable (November 2008) Balázs Égert and Ronald MacDonald

653. An Overview of the OECD ENV-Linkages Model

Jean-Marc Burniaux and Jean Château

652. Reforming the labour market in Japan to cope with increasing dualism and population ageing (November 2008) Randall S. Jones

651. Enhancing the productivity of the service sector in Japan

(November 2008) Randall S. Jones and Taesik Yoon

650. Reforming the tax system in Japan to promote fiscal sustainability and economic growth (November 2008) Randall S. Jones and Masahiko Tsutsumi

649. What Drives the NAIRU? Evidence from a Panel of OECD Countries

(November 2008) Christian Gianella, Isabell Koske, Elena Rusticelli and Olivier Chatal

648. Short-term distributional effects of structural reforms: selected simulations in a DGSE framework (October 2008) Annabelle Mourougane and Lukas Vogel

647. Speed of adjustment to selected labour market and tax reforms

(October 2008) Annabelle Mourougane, Lukas Vogel

646. The challenge of monetary policy in Turkey

(October 2008) Olcay Çulha, Ali Çulha and Rauf Gönenç

645. Improving cost-effectiveness in the health-care sector in Iceland

(October 2008) Hannes Suppanz 
644. Understanding Russian regions' economic performance during periods of decline and growth - an Extreme Bound Analysis approach

(October 2008) Rüdiger Ahrend

643. Do tax structures affect aggregate economic growth? Empirical evidence from a panel of OECD countries

(October 2008) Jens Arnold

642. Accounting for one-off operations when assessing underlying fiscal positions

(October 2008) Isabelle Joumard, Makoto Minegishi, Christophe André, Chantal Nicq and Robert Price

641. Do corporate taxes reduce productivity and investment at the firm level? Cross-country evidence from the Amadeus dataset

(October 2008) Cyrille Schwellnus and Jens Arnold

640. The challenge of rapidly improving transport infrastructure in Poland

(September 2008) Rafal Kierzenkowski

639. Bridging the housing gap in Poland

(September 2008), Rafal Kierzenkowski

638. Improving the business and investment climate in Indonesia

(September 2008), Diego Moccero

637. Growth performance and policy challenges

(September 2008), Luiz de Mello

636. A taxonomy of instruments to reduce greenhouse gas emissions and their interactions

(September 2008), Romain Duval

635. Quantifying the effect of financial conditions on US activity (September 2008) Stéphanie Guichard and David Turner

634. Have long-term financial trends changed the transmission of monetary policy (September 2008), Stéphanie Guichard and David Turner

633. Raising education achievement and breaking the cycle of inequality in the United Kingdom (August 2008) Anne-Marie Brook

632. The euro changeover in the Slovak Republic: implications for inflation and interest rates (August 2008) Felix Hüfner and Isabell Koske

631. Tax reform for efficiency and fairness in Canada (August 2008) Alexandra Bibbee

630. Reforming the Polish Tax System to Improve its Efficiency

(August 2008) Alain de Serres

629. Modernising Canada's Agriculture Policies

(August 2008) Peter Jarrett and Shuji Kobayakawa 